\title{
Modelling the Relationships between Internal Marketing Factors and Employee Job Satisfaction in Oil and Gas Industry
}

\author{
Nazneen Islam Rony ${ }^{1} \&$ Norazah Mohd Suki ${ }^{1}$ \\ ${ }^{1}$ Labuan Faculty of International Finance, Labuan, Malaysia \\ Correspondence: Norazah Mohd Suki, Labuan Faculty of International Finance, Labuan, Malaysia. Tel: \\ 6087-46846. E-mail: azahsuki@yahoo.com
}

Received: January 10, 2017

Accepted: January 24, 2017 Online Published: February 15, 2017

doi:10.5539/ass.v13n3p135

URL: http://dx.doi.org/10.5539/ass.v13n3p135

\begin{abstract}
Employees have long been playing the pivotal role in service organizations to achieve a success-oriented goal. The oil and gas industry is included in the high rising sectors in the world's economy. Due to economic turmoil in this sector, a fear of being laid off remains in an employee's mind. Thus, the goal of this study is to assess the impact between internal marketing factors (e.g., extrinsic and intrinsic employee rewards, leadership, internal communication, and training and development), and employee job satisfaction in the oil and gas industry. There were 215 complete and usable questionnaires received, and the answers varied among the demographic and functional designation within the oil and gas industry. Multiple regressions were utilized for analysis of data. Results revealed that internal communication is recognized to have the strongest effect on employee job satisfaction in the oil and gas industry. Organizations must emphasize on communicating to all level of employees by setting clear directions and key priorities in the organization, provided that the communications are not misled through upward and downward streams. Furthermore, organizations are to create a space for employees to give clear instructions via e-mail, paper, telephones, and face-to-face communication. A management can utilize the research results by conducting such internal marketing practices to keep their top rated employees within the organization.
\end{abstract}

Keywords: internal marketing, job satisfaction, employee rewarding, leadership, training and development, internal communication

\section{Introduction}

Human resources contribute towards the success of business productivity in the global market via its effective branding principles and practices in human resource management area (Alnıç̧ı \& Alnıçık, 2012). "The application of branding principles to human resource management has been termed employer branding" (Backhaus \& Tikoo, 2004, p.501). Organization uses employer branding to promote its image as a right place to work with beside develops awareness among potential and current employees, and stakeholders (Sullivan, 2004). Internal marketing is a new concept in holistic marketing with the belief that satisfied customers come from satisfied employees (Kotler \& Keller, 2009, p.62).

Malaysia is the second largest oil and natural gas producer in Southeast Asia, while being the second largest global exporter of liquefied natural gas due to its strategic location amid important routes for seaborne energy trades. Countries like China, India, Vietnam, and Indonesia were the top four-highest oil reserve producer in the Asia-Pacific area, followed by Malaysia which had four billion barrels as of January 2013 (Oil \& Gas News, 2017). Most of Malaysia's oil comes from offshore fields, including Labuan offshore oil field. As oil and gas industry jobs are complex and concentration-oriented, there remains difficulties for organizations to reduce their employee attrition rate and control high volumes of job switching. Implementing internal marketing would motivate employees to stay focused in meeting customer needs because they have direct dealings with them (Aburoub, Aladwan, \& Hersh, 2011; Gummesson, 2000). Indeed, Gummesson (2000, p.28) states that "an employee's ability to influence and satisfy the needs of others inside the organization is considered an antecedent to external customer satisfaction".

Organization with excellent service quality practices an effective internal customer relationships aiming towards generating satisfied customers. Kotler and Keller (2009) mentions that "satisfied customers come from satisfied employees". Therefore, the issue of implementing strategies like training and development, leadership, rewards, 
and communication within the context of internal marketing to satisfy internal customers are important for organizational service excellence. In reference to this, the goal of this study is to assess the impact between internal marketing (IM) factors (i.e. extrinsic and intrinsic employee rewards, leadership, internal communication, and training and development), and employee job satisfaction in the oil and gas industry.

\section{Literature Review}

This study developed a proposed research framework by using the theory of Berry's Model (1981) and the framework of Al-Hawary, Al-Qudah, Abutayeh, Abutayeh, and Al-Zyadat's (2013) Model as the guiding principle. Berry (1981) noted that employees need enhanced motivation for retention. Berry also noted if the level of employee satisfaction is increased, there is possibility in generating greater external satisfaction and loyalty. Indeed, if an employee is seen as a customer, and a job as a product using the external marketing mix technique, engaging an employee internally would lead to employee satisfaction and thus, attract and maintain customer-oriented employees within the organization.

IM is referred to "the process of attracting, developing, motivating, and retaining qualified employees through job products that satisfy their needs" (Berry \& Parasuraman, 1991, p.151). The impact of IM extends beyond the employee-firm relationship on its ability to link employee satisfaction to superior service quality (Homburg, Hoyer, \& Wieseke, 2009; Sousa \& Coelho, 2013). IM starts right from the beginning of recruitment and selection of the right employees, to selection of a satisfying position and showing positivity in doing work to thus, achieve customer satisfaction (Al-Hawary, 2013). Employees play an important role on customer service as customers need immense attention on personalization and empathy (Boukis \& Gounaris, 2014; Dahl \& Peltier, 2013; Suki, 2014).

The followings section reviews: extrinsic and intrinsic employee rewards, leadership, internal communication, training and development, and employee job satisfaction.

\subsection{Employee Rewards Program}

Both extrinsic rewards and intrinsic rewards, forms of employee motivation or recognition, influences employees work engagement and productivity, job satisfaction, and intention not to switch to other organization (Deci \& Ryan, 1985; Kwasi \& George, 2011; Tymon, Stumpf \& Doh, 2010). The first consists of aspects like pay, promotions and benefits, work location, and working conditions (Sturman, Brown \& Simmering, 2003) while the latter composes receiving positive values for doing meaningful works (Spreitzer, Kizilos \& Nason, 1997; Thomas, 2009; Thomas \& Tymon, 1994, 2009). The strategy to retain good employees involves understanding what they want besides a salary and benefits (Gopal, 2011). Based on prior literature, the following is hypothesized:

H1: Extrinsically rewarding employees positively influence employee satisfaction.

H2: Intrinsically rewarding employees positively influence employee satisfaction.

\subsection{Leadership}

Leadership is defined "as the ability to influence a group towards the achievement of a vision or a set of goals" (Robbins \& Judge, 2014, p.204). Leadership is a process where multilevel leader-follower communication transpires in a particular way to share a purpose and jointly accomplish things willingly (Yammarino, 2012). Moreover, Du Plessis (2010)and Waldman, Ramirez, House and Puranam (2001) stated that a CEO with charismatic style of leadership is responsible of firm's performance where he strategizes the company's planning in line to its vision and mission, monitoring business activities, providing necessary support, and technical assistance towards long-term competitive advantage. Leadership affect the association between the leaders and the employees, and the way they perform changes to achieve a common goal (Du Plessis, 2014). Hence, it is postulated that:

H3: Leadership positively influences employee satisfaction.

\subsection{Internal Communication}

Internal communication is the field of work in an organization that makes or changes the work-related connection among the members of the organization, such as from employee-to-employee, and line manager-to-subordinate to achieve a business goal (Eva, 2012). Earlier scholars noted that high job satisfaction and performance is affected from high power uphold by immediate supervisors (Eva, 2012). Besides, Edelman Trust Barometer (2012) found that businesses that are more trusted "treat employees well" and openly share information. Thomas, Hartman and Zolin (2009) indicated that "when employees perceive that they are getting information from their supervisors and coworkers that is timely, accurate, and relevant, they are more likely to 
feel less vulnerable and more able to rely on their coworkers and supervisors" (Thomas, Hartman and Zolin, 2009, p.302). Subsequently, flow of information would help both employer and employee to be in a win-win situation. Thus, the following hypothesis is posited:

H4: Internal communication positively influences employee satisfaction.

\subsection{Training and Development}

Training is "a systematic process of providing an opportunity to learn the knowledge, skills, and attitudes (KSA) for current or future jobs, whereas development refers to the learning of KSA" (Thacker \& Blanchard, 2006, p.10). Investment in employee training adds significantly towards raising an organizations' performance and productivity (Scott \& Meyer, 1991). Preceding research has suggested that continuous efforts are needed to ensure effective and adequate training is provided to employees in order to achieve organizational goals with a higher degree of commitment, confidence, and satisfaction towards their organization (Bulut \& Culha, 2010; Ehrhardt etal., 2011). Training can also be considered a way to improve employee' satisfaction levels concerning their personal and professional development (Dhar, 2014). Thus, it is hypothesized that:

H5: Training and development positively influences employee satisfaction.

Figure 1 illustrates the proposed theoretical framework anticipating that extrinsic and intrinsic employee rewards, leadership, internal communication, and training and development have a significant effect on employee job satisfaction in the oil and gas industry.

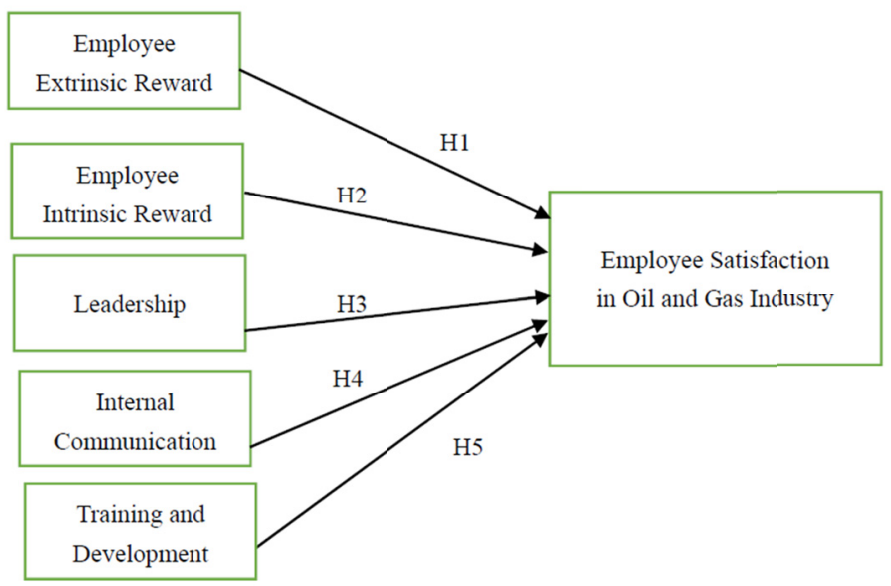

Figure 1. Proposed Theoretical Framework

\section{Research Methodology}

The targeted participants were identified on the basis of their demographic and functional designation within the oil and gas industry in the Federal Territory of Labuan, Malaysia. There were 300 self-administered questionnaires distributed to the respondents, 215 of which were complete and usable with an $83 \%$ response rate. Data was collected from 01 March 2016 to 30 May 2016. The participants were also followed up through phone calls and personal meet-ups at their workplace. The respondents were selected on the basis of simple random sampling whereby each respondent in the population has equal chance to be selected as a sample (Churchill, Brown \& Suter, 2010, p.338).

The questionnaire is designed into three sections. Section A is related to generic information regarding the socio-demographic profile of the respondents, including gender, age, and income. Section B is comprised of questions about the respondents' experiences with internal marketing practices such as frequency of receiving rewards, type of rewards, frequency of training, types of training, scope of leadership, type of interdepartmental employee communication, management, etc. Section C presented scaled questions related to internal marketing factors like extrinsic employee rewards, intrinsic employee rewards, leadership, internal communication, training development, and employee job satisfaction which were measured on a 5 point Likert scale ranging from "1=strongly disagree" to " 5 = strongly agree". Multiple regressions were utilized for analysis of data via the Statistical Package for Social Sciences (SPSS) computer program (version 22) with the main aim to test the effect of independent variables (i.e. employee extrinsic and intrinsic reward, leadership, internal communication, and training and development), and dependent variables like employee job satisfaction in the oil and gas industry. 


\section{Data Analysis}

Table 1 presents the demographic information of the respondents' whereby out of 215 respondents, $59 \%$ were males while $41 \%$ were females. Less than half of the respondents (42.3\%) were aged between $25-30$ years. More than three-quarters of the respondents (77\%) earn a monthly income of less than RM7000 and holds a position of manager, supervisor and cluster head with more than 5 years of working experience in the oil and gas industry.

Table 1. Descriptive statistics of respondents' demographics

\begin{tabular}{|c|c|c|c|}
\hline Variable & & Frequency $(\mathrm{N}=215)$ & Percentage $(\%)$ \\
\hline \multicolumn{4}{|l|}{ Gender } \\
\hline & Male & 127 & 59.0 \\
\hline & Female & 88 & 41.0 \\
\hline \multicolumn{4}{|c|}{ Age (Years) } \\
\hline & $19-24$ & 34 & 15.8 \\
\hline & $25-30$ & 91 & 42.3 \\
\hline & $31-36$ & 59 & 27.4 \\
\hline & $37-42$ & 31 & 14.4 \\
\hline \multicolumn{4}{|c|}{ Monthly Income (RM) } \\
\hline & $<5000$ & 111 & 51.6 \\
\hline & $5001-7000$ & 54 & 25.1 \\
\hline & $7001-10000$ & 25 & 11.6 \\
\hline & $10001-15000$ & 14 & 6.5 \\
\hline & $15001-20000$ & 11 & 5.1 \\
\hline \multicolumn{4}{|c|}{ Department } \\
\hline & Technical & 120 & 55.8 \\
\hline & Non-Technical & 95 & 44.2 \\
\hline \multicolumn{4}{|c|}{ Job Position } \\
\hline & Clerk & 52 & 24.2 \\
\hline & Executive & 83 & 38.6 \\
\hline & Supervisor & 50 & 23.3 \\
\hline & Manager & 22 & 10.2 \\
\hline & Cluster Head & 8 & 3.7 \\
\hline \multicolumn{4}{|c|}{ Working Experience in Oil and Gas Industry } \\
\hline & $1-3$ years & 66 & 30.7 \\
\hline & $3-5$ years & 54 & 25.1 \\
\hline & $5-7$ years & 33 & 15.3 \\
\hline & $7-9$ years & 29 & 13.5 \\
\hline & $>10$ years & 33 & 15.3 \\
\hline
\end{tabular}

\subsection{Reliability Analysis}

Reliability tests were executed on each variable to ensure its measured items are error free and consistent across the various items in the instrument. Results in Table 2 detail that reliability statistics values show a discrepancy from 0.793 to 0.934 , and hence falls within the recommended value of 0.70 by Hair, Black, Babin, Anderson, \& Tatham (2010). Consequently, the questionnaire has high reliability.

Table 2. Reliability analysis

\begin{tabular}{ccc}
\hline Variables & No. of Items & Cronbach's Alpha $(\alpha)$ \\
\hline Employee Extrinsic Reward & 5 & 0.827 \\
Employee Intrinsic Reward & 8 & 0.864 \\
Leadership & 10 & 0.934 \\
Internal Communication & 6 & 0.889 \\
Training and Development & 5 & 0.913 \\
Job Satisfaction & 5 & 0.876 \\
\hline
\end{tabular}




\subsection{Correlation Analysis}

Pearson correlation analysis was performed to test the association between extrinsic employee rewards, intrinsic employee rewards, leadership, internal communication, training and development, and job satisfaction. The correlation coefficients in Table 3 listed that a significant connection exist between all independent variables and dependent variables. For instance, job satisfaction is highly correlated with training and development $((\mathrm{r}=0.650$, $\mathrm{p}<0.01)$, followed by internal communication $((\mathrm{r}=0.6190, \mathrm{p}<0.01)$. Besides, the highest mean value calculated in the total score is associated with employee satisfaction $(\mathrm{M}=3.760, \mathrm{SD}=0.701)$, suggesting a higher level of agreement among the items in this construct. Results imply that on average, the more positive respondents felt about the internal marketing elements, the higher the job satisfaction, bringing towards achieving employee retention.

Table 3. Correlations between constructs

\begin{tabular}{|c|c|c|c|c|c|c|}
\hline Variables & 1 & 2 & 3 & 4 & 5 & 6 \\
\hline (1) Employee Extrinsic Reward & 1 & & & & & \\
\hline (2)Employee Intrinsic Reward & $.584^{* *}$ & 1 & & & & \\
\hline (3) Leadership & $.473^{* *}$ & $.681^{* *}$ & 1 & & & \\
\hline (4)Internal Communication & $.504^{* *}$ & $.535^{* *}$ & $.482^{* *}$ & 1 & & \\
\hline (5)Training Development & $.484^{* *}$ & $.510^{* *}$ & $.556^{* *}$ & $.596^{* *}$ & 1 & \\
\hline (6) Job Satisfaction & $.545^{* *}$ & $.565^{* *}$ & $.577^{* *}$ & $.619^{* *}$ & $.650^{* *}$ & 1 \\
\hline Mean & 3.611 & 3.565 & 3.666 & 3.743 & 3.708 & 3.760 \\
\hline Standard Deviation & 0.881 & 0.7812 & 0.688 & 0.805 & 0.760 & 0.701 \\
\hline Skewness & 2.364 & 1.783 & -0.532 & 2.463 & -0.302 & -0.252 \\
\hline Kurtosis & 19.535 & 14.585 & 0.442 & 19.827 & -0.375 & -0.15 \\
\hline
\end{tabular}

Notes: $* *$ Correlation is significant at the 0.01 level (2-tailed)

\subsection{Relationships on Employee Job Satisfaction in Oil and Gas Industry}

The relationship between internal marketing factors and job satisfaction was established via multiple regressions. The adjusted $\mathrm{R}^{2}$ of this model is 0.558 , meaning that $55.8 \%$ of the variance in the dependent variable is explained by the independent variables (see Table 4). Moreover, the examination of the results confirmed that there is no error in auto-correlation problems as the Durbin-Watson value is close to 2 (i.e. 1.809). The $F$-value is 55.041 , which is highly significant, as $p<0.01$, proving the model will improve the ability to predict the outcome variable.

Table 4. Relationships between internal marketing factors and employee job satisfaction

\begin{tabular}{|c|c|c|c|c|c|c|}
\hline \multirow[t]{2}{*}{ Variable } & \multicolumn{2}{|c|}{$\begin{array}{l}\text { Unstandardized Beta } \\
\text { Coefficients }\end{array}$} & \multirow{2}{*}{$\begin{array}{l}\text { Standardized Beta } \\
\text { Coefficients }\end{array}$} & \multirow[t]{2}{*}{$\mathrm{t}$} & \multirow[t]{2}{*}{ Sig. } & \multirow[t]{2}{*}{ Result } \\
\hline & $\mathrm{B}$ & Std. Error & & & & \\
\hline (Constant) & 0.634 & 0.195 & & 3.247 & 0.001 & \\
\hline Employee Extrinsic & 0.121 & 0.047 & $0.153^{*}$ & 2.578 & 0.011 & H1 Supported \\
\hline Employee Intrinsic & 0.072 & 0.062 & $0.080^{*}$ & 1.151 & 0.251 & H2 Not supported \\
\hline Leadership & 0.172 & 0.067 & $0.168^{*}$ & 2.555 & 0.011 & H3 Supported \\
\hline $\begin{array}{c}\text { Internal } \\
\text { Communication }\end{array}$ & 0.208 & 0.053 & $0.239^{*}$ & 3.914 & 0.000 & H4 Supported \\
\hline Training Development & 0.276 & 0.057 & $0.300^{*}$ & 4.821 & 0.000 & H5 Supported \\
\hline Adjusted $\mathrm{R}^{2}$ & 0.558 & & & & & \\
\hline $\mathrm{F}$ & 55.041 & & & & & \\
\hline Sig & 0.000 & & & & & \\
\hline Durbin-Watson & 1.809 & & & & & \\
\hline
\end{tabular}

Table 4 details the result of the relationships between internal marketing factors and job satisfaction. As expected, extrinsic rewards exert a strong impact on employee job satisfaction $\left(\beta_{1}=0.153, t\right.$-value $\left.=2.578, p<0.05\right)$, specifying that $\mathrm{H} 1$ is held. On the other hand, intrinsic rewards have an insignificant effect on employee job satisfaction $\left(\beta_{2}=0.080, p>0.05\right)$. The results show that $\mathrm{H} 2$ is not sustained. In addition, $\mathrm{H} 3$ postulated that 
leadership positively influences employee job satisfaction. The standardized beta coefficient of the multiple regressions revealed that leadership has a significant effect on employee job satisfaction $\left(\beta_{3}=0.168, t\right.$-value $=$ $2.555, p<0.05$ ), inferring that $\mathrm{H} 3$ is retained. Moreover, $\mathrm{H} 4$ hypothesized that internal communication positively influences employee job satisfaction. The standardized beta coefficient divulge that internal communication significantly affect employee job satisfaction $\left(\beta_{4}=0.153, t\right.$-value $\left.=2.578, p<0.05\right)$, meaning that $\mathrm{H} 4$ is persistent. Finally, H5 posited that training and development positively influences employee job satisfaction. Results in Table 4 details that training and development affect employee job satisfaction $\left(\beta_{5}=0.239\right.$, $t$-value $=3.914, p<0.05)$, hence $\mathrm{H} 5$ is accepted.

\section{Discussion}

This study assessed the impact between IM factors (i.e. extrinsic and intrinsic employee rewards, leadership, internal communication, and training and development), and employee job satisfaction in the oil and gas industry. The empirical results revealed that $\mathrm{H} 1$ is supported, as extrinsic employee rewards positively influence employee satisfaction in the oil and gas industry. Proving that the employees currently serving the organizations are satisfied with their current monthly salary, bonus, and commissions, they will perform in-line with the practical research outcomes of several practitioners (Anik, Aknin, Norton, Dunn, \& Quiboldch, 2013; Geiter and Hofmans, 2015). The hypothesis also confirms that terminal benefits, and updating knowledge through providing training on newly installed technologies reflects employee job satisfaction and intention not to switch to other organization (Deci \& Ryan, 1985; Tymon et al., 2010).

The impact between intrinsic rewards and employee job satisfaction in the oil and gas industry is insignificant, signifying that intrinsic employee rewards do not have any effect on employees to become satisfied and make decisions to remain or quit. Hence, H2 is not maintained. In their study on intrinsic motivational factors in employee job satisfaction and retention within the organization, Samuel and Chipunza (2009) proved a positive results. The study results revealed that employees seldom attend annual conferences organized by the organizations, because they find difficulties in receiving monetary awards for their performance appraisals. Indeed, they feel insecure with the current job received, which proves the lowest mean result in the descriptive analysis in the study. The supervisorial roles are important in helping employees make decisions independently in ad-hoc activities to make the job more exciting and interesting. The highest mean result added that the supervisors should help their employees through giving guidance by showing the right way to do the job.

Further examination of $\mathrm{H} 3$ on whether leadership positively influences employee job satisfaction in the oil and gas industry divulges that this proposition is held. Indeed, this factor has the highest standardized beta coefficient value of all the independent variables and has a significance level of $99 \%$. This result is comparable to that of Amundsen and Martinsen (2014). It affirms that employees seek strong leadership as their guide to provide mental support and co-operation in completing their goals. Employees also find themselves satisfied with their organization and work, which makes them feel self-belongingness and thus, retain for a longer period of time. A transformational leader has the ability to carry out delegation of work among employees, good initiation, and provide a focused goal for attainment (Yammarino, 2012). As the organization is a single entity, a leader should influence all its employees through meaningful, productive, and effective influence (Olaniyan \& Hystad, 2016).

Next, internal communication is recognized to have the strongest positive effect on employee job satisfaction in the oil and gas industry, implying that $\mathrm{H} 4$ is reinforced. Organizations must emphasize on communicating to all level of employees by setting clear directions and key priorities in the organization, provided that the communications are not misled through upward and downward streams, relating to the statement made by Mishra, Boynton, and Mishra (2014). Furthermore, organizations are to create space for employees to have clear instructions via e-mail, paper, telephone, and face-to-face communication. Likewise, the multiple regression analysis results shown that training and development significantly affects employee job satisfaction in the oil and gas industry. Thus, H5 is upheld. This is parallel with the affirmation by Huang and Rundle-Thiele (2015) whereby in internal marketing, training and development plays a formal role to ensure employees are satisfied and will stay. As training and development is an important measure to keep employees up-to-date with knowledge, skills and technologies to sustain a good manpower pool in order to achieve an organizational goal together, organizations are working and doing research continuously to improve their manpower. Organizing proper inductions and orientation programs can help employees to feel comfortable and secure while reflecting the brand image of the organization. Thus, employers should focus more on improving the employees' knowledge, skills, and aptitudes.

\section{Conclusion}

In a nutshell, training and development was found to be the strongest predictors of job satisfaction. The study 
findings provide some important practical implications for research and internal marketing, as employee satisfaction and retention continues to be important research issues for the organizations. Notably, internal communication as well as training and development showed the highest descriptive statistics towards job satisfaction. Successful communication among the co-workers, supervisors and subordinates can create harmony to achieve a goal and sustain development within the organization. Providing ample knowledge through different means, such as on-the-job training or off-the-job training, would let both the organization and employees be in a win-win situation. The organization gets the opportunity to improve in intrinsic and extrinsic rewards for their entry-level employees to retain them for future succession plans. The analysis of the result is an example for managers to follow to identify the loopholes in retaining their highly talented and knowledgeable people for a longer period of time.

Organizational support, rewards, empowerment, and training could be the monitoring factors in providing excellent service quality to customers (Ahsan \& Awan, 2015). Thus, these commitments will affect employee job satisfaction and their service attitude towards peers and customers (Babakus, Yavas, Karatepe, \& Avci, 2003; Bohlander \& Kinicki, 1988; Ferrell \& Hartline, 1996). Organizations must put in more effort on intrinsic rewards as the employees are the internal customers who make the organization a brand to the external customers. To develop commitment from employees and customers, the management team should focus on promising employees job satisfaction (Awan, 2010). According to Deci and Ryan (1985), an employee must feel free from pressure, such as rewards or contingencies. An employee's level of satisfaction toward his job varies with specific aspects of the job (Sarker, 2014) and it depends on such factors like the nature of the work, pay, promotion, co-workers, and organizational context (Sarker \& Shabnam, 2012).

In regards to academic implications, the proposed framework can be used by academicians to extend their research work. This model can be used as an example in other industries, as the study was based on Berry (1981)'s model and Al-Hawary (2013)'s model. It is a terrific opportunity for researchers to collaborate based on the result, and nurture with mediating factors to identify how gender, age and income can create an effect in the workplace. The academicians can take advantage by using more variables, whether dependent or independent, to identify bottlenecks and provide evidence to improve the relationship between management and employee. The additional variables could help find results which would be fruitful to managements to improve weak areas. Secondly, the sample size is 215 , as the area covered is only the Federal Territory of Labuan, Malaysia, which does not represent the whole of Malaysia in general, as there are other places where oil and gas industries are present.

Finally, the industrial coverage is also narrowed down, as the research is conducted only in the oil and gas industry. Future research should blend and extend the involved industries, from the manufacturing of fast moving goods, to many other industries in addition to oil and gas. Although the study has yielded some new insights into the subject matter, it limits the generalization of the coverage of the study. Further research needs to cover the total companies involved with random sampling and have participants spend a longer time period on completing the survey, as the companies have required a number of reminder calls to get the questionnaires complete. Further research should include employee workplace environment and health and safety measures, and its relationship between job satisfaction and employee retention. Expanded number of variables and sample sizes with mediating effects can be included for future study.

\section{References}

Aburoub, A. S., Aladwan, K., \& Hersh, A. M. (2011). Relationship between internal marketing and service quality with customer's satisfaction. International Journal of Marketing Studies, 3(2), 107-118. https://doi.org/10.5539/ijms.v3n2p107

Ahsan, N., \& Awan, A. G. (2015). Impact of quality management practices on the performance of employees: A case study of selected Banks of Pakistan. Research Journal of Finance \& Accounting, 6(13), 134-146.

Al-Hawary, S. I., Al-Qudah, A. K., Abutayeh, M. P., Abutayeh, M. S., \& Al-Zyadat, D. Y. (2013). The impact of internal marketing on employee's job satisfaction of commercial banks in Jordan. Interdisciplinary Journal of Contemporary Research in Business, 4(9), 811-826. https://doi.org/10.1504/ijsom.2013.054445

Alnıaçık, E., \& Alnıaçık, Ü. (2012). Identifying dimensions of attractiveness in employer branding: Effects of age, gender, and current employment status. Procedia-Social and Behavioral Sciences, 58(2012), 1336-1343. https://doi.org/10.1016/j.sbspro.2012.09.1117

Amundsen, S., \& Martinsen, Ø. L. (2014). Empowering leadership: Construct clarification, conceptualization, and validation of a new scale. The Leadership Quarterly, 25(3), 487-511. 
https://doi.org/10.1016/j.leaqua.2013.11.009

Anik, L., Aknin, L. B., Norton, M. I., Dunn, E. W., \& Quoidbach, J. (2013). Prosocial bonuses increase employee satisfaction and team performance. PloS One, 8(9), e75509. https://doi.org/10.1371/journal.pone.0075509

Awan, A. G. (2010). Emerging a new financial paradigm. IUB Journal of Social Sciences and Humanities, 8(2), 73-98.

Babakus, E., Yavas, U., Karatepe, O. M., \& Avci, T. (2003). The effect of management commitment to service quality on employees' affective and performance outcomes. Journal of the Academy of Marketing Science, 31(3), 272-286. https://doi.org/10.1177/0092070303031003005

Backhaus, K., \& Tikoo, S. (2004). Conceptualizing and researching employer branding. Career Development International, 9(5), 501-517. https://doi.org/10.1108/13620430410550754

Berry, L .L. \& Parasuraman, A. (1991). Marketing for Services: Competing through Quality. The Free Press, New York, NY. https://doi.org/10.2307/1252050

Berry, L. L. (1981). The employee as customer. Journal of Retail Banking, 3(1), 33-40.

Boukis, A., \& Gounaris, S. (2014). Linking IMO with employees' fit with their environment and reciprocal behaviours towards the firm. Journal of Services Marketing, 28(1), 10-21. https://doi.org/10.1108/jsm-03-2012-0056

Bulut, C., \& Culha, O. (2010). The effects of organizational training on organizational commitment. International Journal of Training \& Development, 14(4), 309-322. https://doi.org/10.1111/j.1468-2419.2010.00360.x

Churchill, G. A., Brown, T. J., \& Suter, T. A. (2010). Basic Marketing Research (7th ed.). South-Western Cengage Learning.

Dahl, A. J., \& Peltier, J. W. (2014). Internal marketing and employee satisfaction and loyalty: Cross-cultural scale validation in context of US and German nurses. Journal of Consumer Satisfaction, Dissatisfaction and Complaining Behavior, 27(2014), 43-53.

De Gieter, S., \& Hofmans, J. (2015). How reward satisfaction affects employees' turnover intentions and performance: An individual differences approach. Human Resource Management Journal, 25(2), 200-216. https://doi.org/10.1111/1748-8583.12072

Deci, E. L., \& Ryan, R. M. (1985). Intrinsic Motivation and Self-Determination in Human Behavior. New York: Plenum. https://doi.org/10.1007/978-1-4899-2271-7

Dhar, R. L. (2015). Service quality and the training of employees: The mediating role of organizational commitment. Tourism Management, 46(2015), 419-430. https://doi.org/10.1016/j.tourman.2014.08.001

Du Plessis, A. J. (2010). International human resource management: An overview of its effect on managers in global organisations. Interdisciplinary Journal of Contemporary Research in Business, 2(4), 178-192.

Du Plessis, A. J. (2014). Human resource's role with business recovery during and after a recession to engage employees and retain talent. Journal of Community Positive Practices, 14(3), 19-38.

Edelman Trust Barometer. (2012). 2012 Edelman trust barometer: Executive summary. Retrieved from http://www.scribd.com/doc/79026497/2012-Edelman-Trust-Barometer-Executive-Summary. https://doi.org/10.4135/9781483376493.n106

Ehrhardt, K., Miller, J. S., Freeman, S. J., \& Hom, P. W. (2011). An examination of the relationship between training comprehensiveness and organizational commitment: Further exploration of training perceptions and employee attitudes. Human Resource Development Quarterly, 22(4), 459-489. https://doi.org/10.1002/hrdq.20086

Ferrell, O. C., \& Hartline, M. D. (1996). The management of customer-contact service employee: An empirical investigation. Journal of Marketing, 60(4), 52-70. https://doi.org/10.2307/1251901

Gopal, P. (2011). 20 Strategies to retain your best employees. AGD Impact. March, 22-24.

Gummesson, E. (2000). Internal marketing in the light of relationship marketing and network organizations. In Varey, R. J. \& Lewis, B. R., Internal Marketing: Directions for Management, NY, Routledge, 27-42. https://doi.org/10.4324/9780203207352.pt2 
Hair, J. F., Black, B. Babin, B., Anderson, R. E., \& Tatham, R. L. (2010). Multivariate Data Analysis: A Global Perspective. New Jersey: Pearson Education Inc.

Homburg, C., Hoyer, W. D., \& Wieseke, J. (2009). Social identity and the service-profit chain. Journal of Marketing, 73(2), 38-54. https://doi.org/10.1509/jmkg.73.2.38

Huang, Y. T., \& Rundle-Thiele, S. (2015). A holistic management tool for measuring internal marketing activities. Journal of Services Marketing, 29(6/7), 571-584. https://doi.org/10.1108/jsm-03-2015-0112

Kotler, P., \& Keller, K. L. (2009). A Framework for Marketing Management. (4 $4^{\text {th }}$ ed.). Prentice Hall, Pearson Education, Inc.

Kwasi, D. B., \& George, K. A. (2011). Application of Frederick Herzberg's two-factor theory in assessing and understanding employee motivation at work: A Ghanaian perspective. European Journal of Business and Management, 3(9), 1-8.

Mishra, K., Boynton, L., \& Mishra, A. (2014). Driving employee engagement: The expanded role of internal communications. International Journal of Business Communication, 51(2), 183-202.

Oil \& Gas News (OGN), declining production drives new methods of exploration. (2017, January 2). Retrieved from http://www.oilandgasnewsworldwide.com/Article/39916/Declining_production_drives_new_methods _of_exploration\#

Olaniyan, O. S., \& Hystad, S. W. (2016). Employees' psychological capital, job satisfaction, insecurity, and intentions to quit: The direct and indirect effects of authentic leadership. Revista de Psicología del Trabajo $y$ de las Organizaciones, 32(3), 163-171. https://doi.org/10.1016/j.rpto.2016.09.003

Robbins, S. P., \& Judge, T. (2014). Essentials of Organizational behavior (12 $2^{\text {th }}$ ed., Global). Boston: Pearson. P.204

Samuel, O. M. \& Chipunza, C. (2009). Employee retention and turnover: Using motivational variables as a panacea. African Journal of Business Management, 3(8) 410-415.

Sarker, M. A. R. (2014). Increasing employee job satisfaction as well as organizational performance through effective HRM practices in private commercial banking sector of Bangladesh. Journal of Economic \& Sustainable Development, 5(10), 158-164.

Sarker, M. A. R., \& Shabnam, S. (2012). Impact of CSR and internal marketing on employee job satisfaction and organizational commitment: A case study from export-oriented SMEs in Bangladesh. World Journal of Social Sciences, 2(7), 24-36.

Scott, W. R., \& Meyer, J. W. (1991). The rise of training programmes in firms \& agencies-an institutional perspective. Research in Organizational Behavior, 13(1), 297-326.

Sousa, C. M., \& Coelho, F. (2013). Exploring the relationship between individual values and the customer orientation of front-line employees. Journal of Marketing Management, 29(15-16), 1653-1679. https://doi.org/10.1080/0267257x.2013.798674

Spreitzer, G. M., Kizilos, M. A., \& Nason, S. W. (1997). A dimensional analysis of the relationship between psychological empowerment and effectiveness, satisfaction, and strain. Journal of Management, 23(5), 679-704. https://doi.org/10.1016/s0149-2063(97)90021-0

Sturman, M. C., Brown, M. P., \& Simmering, M. J. (2003). Compensation policy and organizational performance: The efficiency, operational, and financial implications of pay levels and pay structure. Academy of Management Journal, 46(6), 752-762. https://doi.org/10.2307/30040666

Suki, N. M. (2014). Passenger satisfaction with airline service quality in Malaysia: A structural equation modeling approach. Research in Transportation Business \& Management, 10(2014), 26-32. https://doi.org/10.1016/j.rtbm.2014.04.001

Sullivan, J. (2004). Eight elements of a successful employment brand. Retrieved from http://www.erexchange.com/articles/db/52CB45FDADFAA4CD2BBC366659E26892A.asp

Tariszka-Semegine, E. (2012). Organizational internal communication as a means of improving efficiency. European Scientific Journal, 8(15), 86-96.

Thacker, J. W., \& Blanchard, P. N. (2006). Effective Training (2nd ed.). India: Prentice-Hall

Thomas, G., Zolin, R., \& Hartman, J.L. (2009). The central role of communication in developing trust and its effect on employee involvement. International Journal of Business Communication, 46(3), 287-310. 
https://doi.org/10.1177/0021943609333522

Thomas, K. (2009). Four intrinsic rewards that drive employee engagement. Ivy Business Journal. Retrieved from http://iveybusinessjournal.com/publication/the-four-intrinsic-rewards-that-drive-employee-engagement/

Thomas, K. W., \& Tymon, W. G. (1994). Does empowerment always work: Understanding the role of intrinsic motivation and personal interpretation? Journal of Management Systems, 6(2), 1-13.

Thomas, K.W ., \& Tymon, W. G. (2009). Work Engagement Profile. Mountain View, Canada: CPP.

Tymon, W. G., Stumpf, S. A., \& Doh, J. P. (2010). Exploring talent management in India: The neglected role of intrinsic rewards. Journal of World Business, 45(2), 109-121. https://doi.org/10.1016/j.jwb.2009.09.016

Waldman, D. A., Ramírez, G. G., House, R. J., \& Puranam, P. (2001). Does leadership matter? CEO leadership attributes and profitability under conditions of perceived environmental uncertainty. Academy of Management Journal, 44(1), 134-143. https://doi.org/10.2307/3069341

Yammarino, F. J. (2012). Leadership. Encyclopedia of Human Behavior (2nd ed.).

\section{Copyrights}

Copyright for this article is retained by the author(s), with first publication rights granted to the journal.

This is an open-access article distributed under the terms and conditions of the Creative Commons Attribution license (http://creativecommons.org/licenses/by/4.0/). 